not be arranged for those with say 3 to 4 years service overseas to exchange with an equal number of the younger members of the E.M.S. who have seen no service abroad? 'Wè would not mean to imply that the E.M.S. ophthalmologists have been having an easy time. They most certainly have not; and all have been in a sense in the front line and on active service. But active service in Great Britain, however hard the work may have been and however long the hours, is not quite the same as service in India, Africa, or on the continent-as in Italy. Looking to the future it seems to us that it is of the greatest importance for those who have been so long on foreign service to have no extra source of grievance when they return to civil life. The suggestion of an exchange seems to us a reasonable way of solving a possible source of trouble in after years. And we would respectfully ask the powers that be to consider the suggestion.

\title{
THE FACULTY OF OPHTHALMOLOGISTS
}

As already announced to the medical press, the Council of British Ophthalmologists has sponsored the formation of a Faculty of Ophthalmologists which it is intended should be a body representative of all British Ophthalmologists. The Council of the Faculty was elected by ballot and consists of regional and national representatives. The result of the election was as follows :-

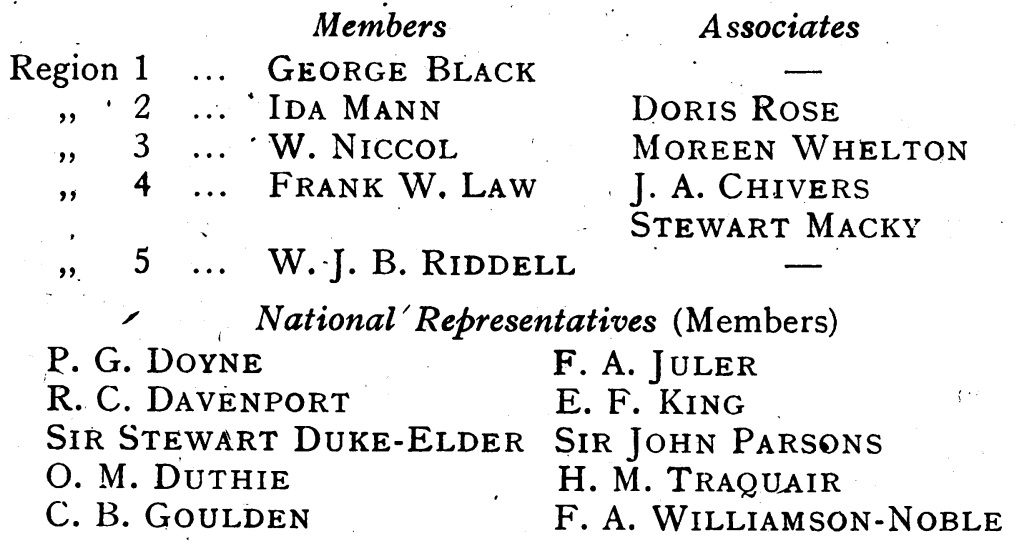

At its first meeting the Council elected the following officers :$\begin{array}{ll}\text { President: } & \text { SIR STEWART DUKE-ELDER } \\ \text { Vice-President: } & \text { F. A. JULER } \\ \text { Hon. Treasurer: } & \text { F. A. WILlIAMSON-NOBLE } \\ \text { Hon. Secretary: } & \text { FRANK W. LAW }\end{array}$

The criteria of membership and other details were necessarily temporary owing to the urgency of the political situation. These 
will naturally require modification; with this in view a meeting was arranged, under the Chairmanship of the President of the Royal College of Surgeons, between four representatives each of the Faculty, the Ophthalmic Group Committee of the British Medical Association, and the Association of British Ophthalmologists. This body met on May 8 and the results of its deliberations will be published in due course.

At its first meeting the Council elected Standing Committees on Medico-politics, Education and Research, and Remuneration and Emoluments.

\author{
Frank W. LaW, \\ Hon. Secretary,
}

Faculty of Ophthalmologists.

\title{
ABSTRACTS
}

\section{MISCELLANEOUS}

(1) Galton, E. M. G. (R.A.M:C.)-Treatment of perforating corneal ulcer. Lancet, 247, p. 242, 1944.

(1) Galton describes his technique for treating perforating corneal ulcers in 15 Italian soldiers. The patients received preoperative treatment for three or four days. This consisted of irrigating the conjunctival sac with either saline or hydrarg. perchloride lotion $1: 10,000$; sulphanilamide $8,6,6,6$ grammes by mouth and sulphanilamide powder dusted into the lower fornix. The diet was augmented by cod-liver oil, " marmite" and oranges.

The site of the perforating corneal ulcer was covered by a "visor" conjunctival flap. When the ulcer was central flaps were brought down from above and up from below and joined by mattress sutures. The author had no difficulty in separating iris which had been prolapsed for over seven days. He states that by bandaging both eyes the conjunctival flap remains longer in position and does not retract as early as it does when one eye only is covered. In the series both eyes were bandaged for four days. In every case the corneal ulcer healed and there were no septic complications.

H. B. Stallard.

(2) Greeves, R. A. (London).-Retrobulbar optic neuritis. A pathognomonic sign. Lancet, i, p. 715, 1944.

(2) Greeves comments that it is not commonly known that the tenderness elicited by pressure on the eyeball in cases of retrobulbar neuritis is limited to a spot in the mid-line roughly corresponding 


\section{NOTES}

Death

Doctor CARL HAMBURGER, sometime of Berlin, died in May, 1944, in Gland, near Geneva, where he had found refuge as an exile from Germany in 1939. His studies dealt chiefly with the physiology of nutrition of the eye and with problems of glaucoma. His "Experiences with Glaucosan" were published in the Brit. Jl. Ophthal., for August, 1936.

His wife, the daughter of Prof. Herman Cohn, of Breslau, died in 1942.

White Oak Hospital, THE following are the admissions recorded for Swanley. 1942 and 1943 :-

$\begin{array}{llllrr} & & & & 1942 & 1943 \\ \text { Phlyctenular ophthalmia } & & \ldots & \ldots & 121 & 96 \\ \text { Blepharitis } \ldots & \ldots & \ldots & \ldots & 87 & 79 \\ \text { Interstitial keratitis } & \ldots & \ldots & \ldots & 5 & 10 \\ \text { Trachoma .. } \ldots & \ldots & \ldots & \ldots & 5 & 7 \\ \text { Acute conjunctivitis } & \ldots & \ldots & \ldots & 3 & 3 \\ \text { Chronic conjunctivitis } & \ldots & \ldots & \ldots & 16 & 11 \\ \text { Miscellaneous } \ldots & \ldots & \ldots & \ldots & 24 & 23 \\ & & & & & \\ \end{array}$

In 1942 there were in addition also admitted-128 babies and 98 nursing mothers to the ophthalmia neonatorum block. The corresponding figures for 1943 were 142 and 114 . The hospital provided hospitality to 113 nursery babies in 1942 and to 217 in 1943.

Corrigendum

DR. MUTCH points out that the legend for Fig. 4 in his paper on the lacrimation reflex, p. 323, should read "Area of anaesthesia after section of the sensory root of the 5th nerve on the left side," and not as was printed.

Special Notice

WE are asked by the Ministry of Information to state that the fact that goods made of raw materials in short supply owing to war conditions are advertised in this journal should not be taken as an indication that they are necessarily available for export. 